\title{
The implementation of community development participation (KKN) based literacy education in Central Lombok
}

\author{
Muhammad Arief Rizka, Akhmad Sukri *, Dira Permana \\ Universitas Pendidikan Mandalika. Jalan Pemuda No.59A, Mataram, 83125, Indonesia \\ *Corressponding Author. Email: akhmadsukri@ikipmataram.ac.id
}

Received: 11 February 2020; Revised: 2 March 2020; Accepted: 29 April 2020

\begin{abstract}
This study aimed at analyzing the implementation of Thematic Community Service Program based basic literacy education of IKIP Mataram in the Central Lombok District which included registration, debriefing, implementation, monitoring, evaluation, and identification of the obstacles to implementation in the field. The research method used in this research was a descriptive method by combining quantitative and qualitative approaches. The subjects of this study were the Chairperson of the Institute for Research and Community Service IKIP Mataram, the Organizing Committee, Community Service Students, Field Counseling Lecturers, Village Heads, and Literacy Education Students. Data collection instruments used were questionnaires, interviews, observation, and documentation guidelines. The data analysis technique used was qualitative and quantitative descriptive analysis. The results of this study showed that; (1) the implementation of basic literacy education based Thematic Community Service Program at IKIP Mataram has been carried out through the stages of registration, debriefing, implementation, monitoring, and evaluation; (2) The results of the evaluation of the implementation of Basic Literacy Education learning have succeeded in teaching 802 illiterate people in Central Lombok district with data on the results of the basic literacy tests that have been carried out as many as 552 people have learned and declared passed and as many as 250 people declared not passed or do not yet meet the Minimum Completeness Criterion of Basic Literacy Assessment; and (3) The main obstacle of the implementation of the Thematic KKN program is the earthquake disaster that struck the island of Lombok and has implications on the minimum resident's basic literacy learning implementation in the field. However, Community Service students with DPL assistance, the Village Head, and the LPPM Team have made an optimal effort so that the implementation of the Thematic KKN can continue to run in the community.
\end{abstract}

Keywords: thematic community service, literacy education, KKN.

How to Cite: Rizka, M., Sukri, A., \& Permana, D. (2020). The implementation of community development participation (KKN) based literacy education in Central Lombok. JPPM (Jurnal Pendidikan dan Pemberdayaan Masyarakat), 7(1), 23-35. doi:https://doi.org/10.21831/jppm.v7i1.30133

\section{INTRODUCTION}

Higher education has a mission that is termed as Tri Dharma as written in the Republic of Indonesia Law Number 12 of 2012 concerning Higher Education, Article 1 paragraph 9 states that: "Tridharma of Higher Education, hereinafter referred to as Tridharma, is the obligation of the Higher Education Institution to carry out education, research, and community service." One of the implementations of the tri dharma of the tertiary institution is through the Community Service Program (KKN) conducted by students (Rizka, 2016). KKN program is one of the compulsory courses in the IKIP Mataram study curriculum and must be taken by all undergraduate students (S-1). KKN program is an extracurricular activity that combines the implementation of the tri dharma of tertiary institutions (education, research, and community service) by giving students an experience of learning and working in community empowerment activities as a vehicle for application and development of knowledge carried out outside campus in time, certain mechanisms and requirements (Institute for Research and Community Service (LPPM IKIP Mataram, 2014). Besides, KKN is carried out in a cross-sectorial and interdisciplinary manner in the community by students with the guidance of lecturers (Basukiyatno et al., 2004). 


\section{JPPM (Jurnal Pendidikan dan Pemberdayaan Masyarakat), 7 (1), 2020 - 24}

Muhammad Arief Rizka, Akhmad Sukri, Dira Permana

KKN program in IKIP Mataram is an integrated part of the education process and is a subject that is prepared to develop student competencies through real experience in the community. Through this experience, students are expected to gain generative abilities in the form of life skills such as the ability to think and reason analytically based on empirical and realistic sources, that they can design and implement programs, help overcome existing problems, work together with others, organize themselves and practice skills at work. KKN activities are a tangible form of the IKIP Mataram contribution to the community, local government and community groups who want to be economically and socially independent. The concept of 'working with the community' has replaced the concept of 'working for the community'. Some strategies adopted in implementing KKN include the concept of community empowerment through the development of contextual KKN themes in partnership with local governments and developing KKN themes with the concepts of co-creation, co-financing, and co-benefit (LPPM IKIP Mataram, 2014).

In the 2018/2019 academic year, IKIP Mataram began to change the pattern of KKN program implementation that was previously held with an integrated concept with the teaching practice program (PPL) into a Thematic KKN program. This change in pattern is part of an effort to serve the needs of the community so that the implementation of $\mathrm{KKN}$ is more effective and as a vehicle for the development of student competencies that are productive, innovative, and characterized (in line with the vision of the Mataram Teachers' Training Institute). Thematic $\mathrm{KKN}$ is a real Community Service program with a focus on specific learning outcomes that are relevant to regional or central government development programs, relevant to community needs, and relevant to the vision, mission, strategic plan, expertise, and science and technology of IKIP Mataram. The theme of the implementation of the Thematic KKN at Mataram IKIP in the academic year 2018/2019 held was "Basic Literacy Education". The rationale for the selection of the Thematic KKN theme is the urgency of the problem of the high illiteracy rate in the province of West Nusa Tenggara (NTB), were based on 2017 data NTB ranked second in illiteracy in Indonesia aged 15-59 years with a percentage of 7.91 percent. This position is below Papua, which occupies the number one illiterate position in Indonesia, which is 28.75 percent (Rasyid, 2017).

Efforts to alleviate illiteracy are very important in human development. United Nations Development Programme (UNDP) makes literacy as one of the variables of the four determinants of a country's human development index (HDI) or human development index (HDI) (Shantini, 2010). To overcome the illiteracy problem in a region, the implementation of basic literacy education is needed. Literacy education is carried out as a way to remember, record, express reality, and communicate across space and time. This can be interpreted that learning literacy is not just learning to read, but also learning to write. Reading, writing, and arithmetic are basic literacy abilities that must be possessed by someone to be able to recognize letter numbers (Masniladevi et al., 2018). The activity of taking notes is one of the implementations of the writing activity. What things are recorded by students are things related to their daily lives (Retnowati, 2015). Basic literacy education is an educational service for Latin illiterates aged 15-59 years, priority 45 years and above to have attitudes, knowledge, skills in using Indonesian, reading, writing and arithmetic, to support daily activities in life family and community (Wulandari, 2018).

The implementation of Basic Literacy Education should be in accordance with the Regulation of the Minister of Education and Culture of the Republic of Indonesia Number 86 the Year 2014 concerning the Implementation of Basic Literacy Education. One of the supports for the implementation of basic literacy education in accordance with the curriculum is the availability of teaching materials, syllabus, and lesson plans, learning guides, assessment guides that refer to the basic literacy education curriculum. With the existence of teaching materials, syllabus and lesson plans, learning guides, basic literacy education assessment guides are expected to be able to provide knowledge, skills in accordance with the expected competency standards (Nurazizah, 2018). The learning process applied to the literacy education program so 


\section{JPPM (Jurnal Pendidikan dan Pemberdayaan Masyarakat), 7 (1), 2020 - 25}

Muhammad Arief Rizka, Akhmad Sukri, Dira Permana

far only introduces letters and numbers only. As a result, learning is not attractive to learning citizens. This condition can be seen from the decreasing level of attendance and community involvement in the learning process. This requires education practitioners to find innovations and learning strategies that are more focused on meeting the life needs of learning citizens. Bearing in mind that citizens learning literacy programs are adults who are oriented towards meeting their needs (Indrianti et al., 2017).

The strategy for accelerating illiteracy eradication involves choices about appropriate learning models, or which are efficient and effective in teaching reading and writing for building awareness, increasing the ability to analyze life problems, and improving life (Kuntoro, 2007). Besides, in overcoming the problem of illiteracy (literacy) not only can be done by one party, but it requires the involvement of various parties (Oktapiani et al., 2019) so that it is hoped that through the implementation of the Thematic KKN Basic Literacy Education organized by IKIP Mataram minimizes the high problem illiteracy in the NTB province so that it can contribute in realizing literacy communities. The purpose of this research is to describe the implementation of the IKIP Mataram Thematic KKN program which includes registration, provisioning, implementation, monitoring, evaluation, and implementation constraints so that objective information is obtained regarding the effectiveness of the program implementation in the field.

\section{METHOD}

The method used in this research was a descriptive method by combining quantitative and qualitative approaches. In collecting data of the research, the informants or respondents were the parties directly involved in the implementation of the Thematic Community Service (KKN) at IKIP Mataram in academic year 2018/2019, which were the Chairperson of Institute for Research and Community Service (LPPM), the Organizing Committee, Community Service Students, Field Counseling Lecturers (DPL), Village Heads, Learning Citizens of Literacy Education. Respondents were selected using a purposive sampling technique by taking the principle of proportionality into account. Data collection instruments used were questionnaires, interview guidelines, observation guidelines, and documentation guidelines. Besides, there has been also a process of collecting data and information through informal discussions or dialogues. Data analysis techniques used in this study were: (1) Descriptive statistical analysis displayed graphically to facilitate understanding and interpretation of data. For the evaluation criteria of the questionnaire data, a formulation of assessment criteria was designed using fidelity techniques (Rizka, 2014); and (2) Qualitative descriptive analysis is performed to describe and analyze data and to clarify the information contained in the statistical display.

\section{RESULTS AND DISCUSSION}

The implementation of Thematic Community Service Program (KKN)-based basic literacy education of IKIP Mataram in academic year 2018/2019 was held in Central Lombok District, NTB Province. The selection of Central Lombok Regency as the location of the Thematic KKN implementation is because the district is one of the districts in NTB province that still has a high level of illiteracy. To facilitate understanding related to the implementation profile of the Thematic KKN program, the following data table is displayed (Table 1).

Based on the data Table 1 , the implementation of the Thematic Community Service (KKN) program of IKIP Mataram in academic year 2018/2019 found that there were 487 students of Community Service (KKN) with 62 Field Counseling Lecturers (DPL) and 62 villages in total of Thematic KKN locations of 5 districts in the district of Central Lombok, with details of the number of Thematic KKN students in Pujut sub-district as many as 111 people, Kopang subdistrict as many as 110 people, Central Praya sub-district as many as 78 people, East Praya subdistrict as many as 88 people, and Janapria sub-district as many as 100 students. 
JPPM (Jurnal Pendidikan dan Pemberdayaan Masyarakat), 7 (1), 2020 - 26

Muhammad Arief Rizka, Akhmad Sukri, Dira Permana

Tabel 1. Data of Thematic Community Service (KKN) Program of IKIP Mataram

\begin{tabular}{cccccc}
\hline No. & \multicolumn{1}{c}{ Period } & $\begin{array}{c}\text { Total of } \\
\text { participants }\end{array}$ & $\begin{array}{c}\text { Total of Field Counseling } \\
\text { Lectures (DPL) }\end{array}$ & Subdistrict & Village \\
\hline 1. & $\begin{array}{l}\text { T.A 2018/2019 } \\
\text { Total }\end{array}$ & $\begin{array}{c}487 \\
\text { T87 Students }\end{array}$ & 62 & 5 & 46 \\
\hline
\end{tabular}

Registration for Thematic Community Service Program-based Basic Literacy Education

The registration activity is the initial stage that is passed by prospective students participating in Thematic KKN. In the registration activity, all prospective participants must meet the administrative requirements and completeness as part of the selection effort for Thematic KKN participants. To be able to support the registration process so that it runs in an orderly manner according to procedures, LPPM IKIP Mataram held pre-briefing activities before the registration process took place. The pre-briefing activity aims to provide technical information related to the implementation of Thematic KKN in general to all prospective participants. Specifically, the prebriefing activities also provide comprehensive information related to the registration process, which includes mechanisms, administrative requirements, technical activities, financing, and soon.

The mechanism or process of registration for the Thematic KKN program at IKIP Mataram in academic year 2018/2019 is designed as follows; (1) students carry out the process of verifying academic data in their respective study programs; (2) Study program determines the feasibility of prospective students participating in KKN by referring to the educational guidelines for the IKIP Mataram; (3) the results of data verification by each Study Program will then be submitted to LPPM as a basis for knowing the number of prospective Thematic KKN participants; (4) students who are deemed eligible as potential KKN participants (after fulfilling academic requirements) take the registration form and submit administrative requirements documents or files to LPPM for verification by the registration committee; and (5) the results of verification of student documents by the registration committee become the basis for determining which students are eligible to attend the debriefing process and the next stage.

To be able to meet the needs of prospective Thematic KKN participants, LPPM IKIP Mataram strives to be selective by conducting a check-recheck process related to student academic and administrative data. This process is carried out as part of efforts to improve the quality of inputs for the implementation of the Thematic KKN program. The requirements that must be met by prospective students participating in the Integrated PPL-KKN include; (1) registered as an IKIP Mataram student in the S1 program in the semester the Thematic KKN program is held; (2) has taken a minimum of 106 credits with a minimum Grade Point Average (GPA) of 2.5; and (3) program KKN courses in the Study Program Card (KRS) with a maximum of credit points taken is 16 credits.

For the efficiency and effectiveness of activities, the registration process time is set in such a way that it can run in an orderly and smooth manner. Each faculty and study program is given proportional distribution of registration time to be able to provide optimal registration process services for prospective students participating in the Community Service Program.

In the registration activities, based on the analysis of questionnaire data related to student responses to the implementation of the registration process, it can be concluded that the activities of the Thematic KKN registration stage of the academic year 2018/2019 are a good category. This is showed in students' responses to indicators of registration activities which include; information socialization, requirements, registration mechanism or flow, and services. To facilitate the understanding of student responses to the KKN registration activities, a chart is displayed (Figure 1). 
JPPM (Jurnal Pendidikan dan Pemberdayaan Masyarakat), 7 (1), 2020 - 27

Muhammad Arief Rizka, Akhmad Sukri, Dira Permana

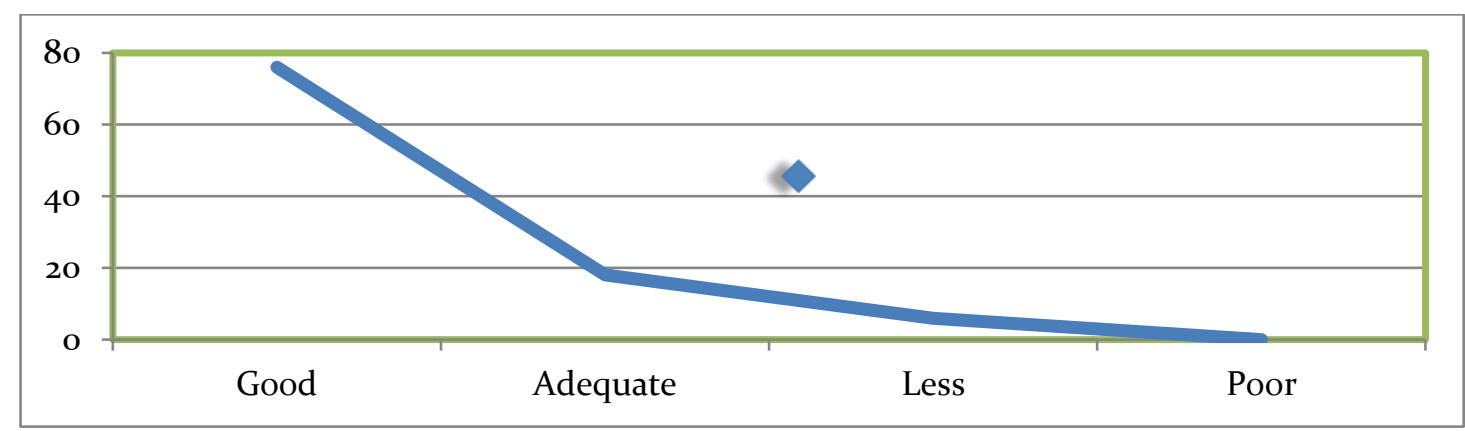

Figure 1. Response to Thematic KKN Registration

Based on Figure 1, it can be explained that as much as $64.71 \%$ responded that the implementation of the Thematic KKN registration activities at IKIP Mataram in academic year $2018 / 2019$ has been implemented well; while as many as $35.29 \%$ gave a fairly good response.

During the process of registration, the findings in the field related to the problems that arise are that there are some students have the low ability to accessing information related to the mechanism and requirements of KKN registration, causing the registration process to be constrained (in-efficient). To overcome various technical problems that arise in the registration activities, LPPM IKIP Mataram seeks to overcome them through a persuasive communication approach to students to actively seek information through various media used by LPPM IKIP Mataram, that the mis information problem can be minimized.

Based on an analysis of the KKN registration activities that have been carried out, there are constructive inputs provided by 'stakeholders' which can be used as an improvement material for a better registration process going forward. These inputs include, namely; (1) KKN registration activities are strived to consider proportional time aspects between study programs/ faculties to be able to provide optimal registration process services; (2) submitting KKN registration form/document requirements to be arranged in such a way as to involve all study programs/departments and LPPM operators so that the process can run more efficiently and effectively; and (3) registration activities are expected to be carried out following the schedule in the academic calendar of IKIP Mataram. If there is a change in schedule with the academic calendar it is expected that the intensity of information dissemination will be increased and expanded.

\section{Provision of Thematic Community Service Program-based Basic Literacy Education}

Debriefing activities are the stages that are carried out after the registration process. At this stage of the defence activity, students as prospective Thematic KKN participants have been grouped based on consideration of proportionally determined location (village) needs. This Thematic KKN debriefing activity has objectives including; (1) giving students an understanding and appreciation of the basic concepts, meanings, objectives, approaches, programs, implementation, monitoring, and evaluation of the Thematic KKN program; (2) providing knowledge, attitudes, and values to students to enter the education and community system in the Thematic Community Service Program; (3) provide information about the situation, conditions, potential, and problems that are the locations of Thematic KKN; (4) provide insights to students about managing functional literacy education programs; (5) providing knowledge and practical skills to students in order to carry out their programs and assignments at the KKN location; (6) providing the ability to be able to work together in implementing KKN programs in an interdisciplinary and cross-sectorial manner; and (7) providing the ability for students to manage themselves (using time) efficiently and effectively when implementing the Thematic Community Service Program.

This learning activity has been set in such a way in terms of time management, place, and determination of technical sources. This is important to be carried out in order to realize the effective and efficient implementation of Thematic KKN debriefing activities. The debriefing 
JPPM (Jurnal Pendidikan dan Pemberdayaan Masyarakat), 7 (1), 2020 - 28

Muhammad Arief Rizka, Akhmad Sukri, Dira Permana

activity was held on Saturdays which were scheduled periodically. The timing is with the consideration that the debriefing activities do not interfere with the lecturing activities of students and lecturers so that the debriefing process can be more intensively carried out.

The material for Thematic KKN debriefing consists of general material and special material. General material contains the Community Service Philosophy, Group Dynamics, Community Ethics, and Communication \& Conflict Management. Whereas the special material covers material on the Concept of Literacy Education, Andragogy Learning, Identification of Needs \& Preparation of Basic Literacy Teaching Materials, Strategies \& Methods of Basic Literacy Learning, and Literacy Assessment. The speakers in this Thematic KKN debriefing activity came from internal and external IKIP Mataram. The speakers coming from internal IKIP Mataram are from the campus leadership elements, lecturers, and practitioners. While external speakers included the Head of the Education Office of Central Lombok District, Head of PAUD Dikmas Disdik Regency, Kasi Dikmas Disdik, and Kasi Dikmas BP PAUD Program. In addition, in the future debriefing material session, it is expected to be able to provide opportunities for students (alumni of KKN participants) who 'excel' as reference materials and best practices for examples for other Thematic KKN participants.

In an effort to improve the quality of Thematic KKN participants, LPPM IKIP Mataram also held the KKN Debriefing Test. This debriefing test was held be able to map the abilities or competencies of prospective KKN participants and to be a selection process for the eligibility of students to be placed in the Thematic KKN village location. In carrying out the debriefing test, the requirements or graduation indicators specified include; (1) follows debriefing in an orderly and disciplined manner; (2) meet attendance at least 85\%; (3) follow and pass the deepening of the debriefing material; (4) get a test score with a minimum score of $65 ;(5)$ and pass the practice of literacy learning with a minimum score of 70 . So far, the provisioning test activities, based on field observations can contribute to improving the competency or the ability of participants to understand and apply the debriefing material at the KKN location. In addition, findings in the field were based on interviews with KKN participants that the debriefing activity had benefits for students.

In the debriefing activities, based on the analysis of questionnaire data related to the students' responses to the debriefing activities, it can be concluded that the Thematic KKN debriefing activities in the academic year 2018/2019 are in the very good category. This is indicated by students' responses to the indicators of debriefing activities which include; facilities (facilities), speakers, material, time, and supporting infrastructure conditions. To facilitate the understanding of student responses to the KKN debriefing activities (Figure 2).

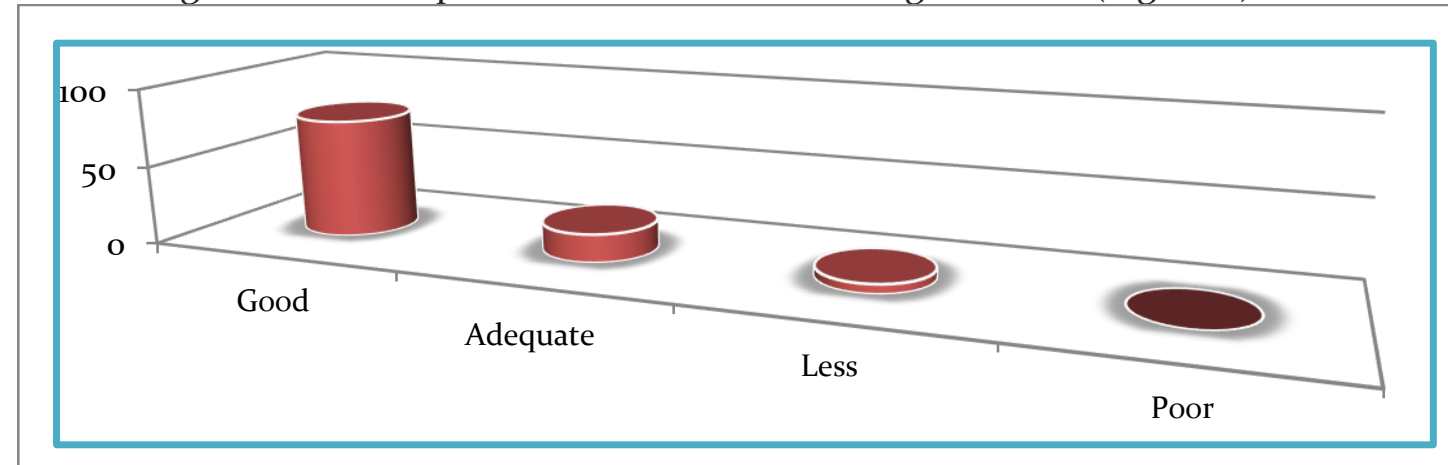

Figure 2. The Response of KKN Debriefing

Based on Figure 2, it can be explained that as many as $44.75 \%$ responded that implementation of the Thematic KKN debriefing activities at IKIP Mataram in academic year 2018/2019 had been carried out well, while as many as $55.25 \%$ gave quite good responses. During the debriefing process, field findings were related to problems that arose, among others; (1) some students are not disciplined and focused to follow the process of delivering material briefing which has implications for the low ability of students to answer and complete the debriefing test questions; 
JPPM (Jurnal Pendidikan dan Pemberdayaan Masyarakat), 7 (1), 2020 - 29

Muhammad Arief Rizka, Akhmad Sukri, Dira Permana

(2) the low attitude of curiosity (curiosity) of students to ask more questions related to the material and examples of experience in the field; (3) there are still speakers who do not deliver substantial material that causes the achievement of objectives or competency standards that are not expected to be achieved optimally; (4) some students lack discipline such as being late or not on time to attend debriefing activities and not carrying equipment (ATK) and students are still found not wearing clothes that reflect the figure of an educator and educational staff; and (5) limited time availability in the delivery session for material delivery which makes the speakers not optimal for elaborating on the material presented.

To overcome and minimize the problems that arise during the debriefing activities, LPPM IKIP Mataram seeks to apply the strategy and approach to the debriefing process both in terms of the delivery of material and other technical aspects in a cooperative, participatory, and fun manner, such as in the process of delivering the material, some speakers displaying animations or motivational video shows that are edutainment so as to increase the enthusiasm of students to follow debriefing activities. In addition, to improve student discipline in following the debriefing process, binding rules were made in the form of both written and oral sanctions as a 'punishment' effort in order that students could be disciplined and disciplined in the process of debriefing thematic KKN.

Based on the results of interviews with several 'stakeholders', there were some constructive inputs that were conveyed to improve the quality of debriefing activities. These inputs involve; (1) specifically in the aspect of the delivery of the debriefing material, it is expected that the speakers of the materials will deliver the material in accordance with the specified objectives; (2) to increase comfort in the debriefing process, it is expected that the division of groups that have been formed is more proportional and adjusted to the condition of the existing infrastructure; (3) facilities and equipment (sound system, fan, LCD) for the provisioning activities are more carefully prepared so that the defence process can take place to the maximum; (4) the duration of time for delivery of material to be supplemented so that the process of delivering material can be more optimal; and (5) debriefing activities need to be set more creatively through the concept of 'edutainment' concept to increase motivation and atmosphere of more pleasant debriefing activities.

\section{Implementation of Thematic Community Service Program-based Basic Literacy Education}

Implementation Description

The implementation of Thematic Community Service Program-based Basic Literacy Education was held with a total number of participants as many as 509 students, where the number of illiterate learning people who were targeted by the program was 812 people. Based on field observations, most students at the beginning of the activity were very enthusiastic and active in carrying out the KKN assignments. In the implementation of this Community Service Program, students have a collective responsibility for the activities that have been carried out, under the guidance of the Village Head and the DPL who coordinate with each other. However, in the process of the Thematic KKN program in the field, coinciding with the 5 August 2018 earthquake disaster with a scale of 7.0 Richter struck Lombok Island, causing psychological and physical impacts for all Thematic KKN participants. This has become an obstacle and obstacle for the implementation of the Thematic Community Service Program, considering that the earthquake that occurred not only once happened but the aftershock of earthquakes that reached hundreds of times so that several groups of students of KKN were less optimal in implementing programs in the field.

Although the implementation of the Thematic KKN program in the field in disaster conditions does not dampen the enthusiasm of KKN students to continue educating illiterate citizens to learn. During disaster conditions, the KKN group continues to carry out learning and mentoring for residents to learn in modest conditions. Based on the questionnaire data analysis 
JPPM (Jurnal Pendidikan dan Pemberdayaan Masyarakat), 7 (1), 2020 - 30

Muhammad Arief Rizka, Akhmad Sukri, Dira Permana

related to the performance of students in carrying out $\mathrm{KKN}$, it can be concluded that students in carrying out Thematic KKN on Literacy Eradication are in a good category. This can be shown from the achievement of student performance in implementing KKN program which includes; work program management, collaboration, communication, and participation. To facilitate understanding of the achievement of student performance in KKN programs, the following chart is displayed (Figure 3).

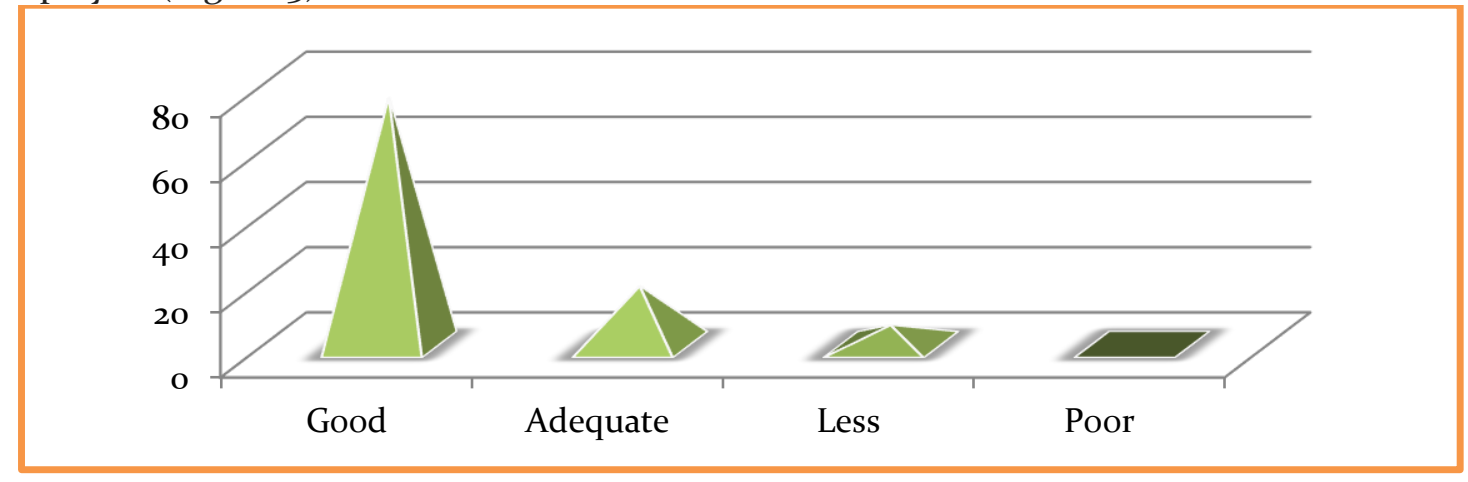

Figure 3. Student Community Service Work Performance

Based on Figure 3, it can be explained that as much as $75 \%$ responded that student performance in implementing the Community Service Program was good, as much as $20 \%$ was quite good, and as much as $5 \%$ was not good. Based on the findings in the field, students who are not good enough in carrying out Thematic KKN can be indicated from the lack of students' ability in terms of communication skills with community leaders and villagers so that it often causes miscommunication, there are still students who 'error' in the field such as the level of attendance ( participation and cooperation) are minimal, there are still students who are doing non-productive activities and that are not in accordance with their tasks and some students who are shocked by the earthquake disaster, causing trauma to return to the KKN post.

The main tasks of DPL in the Thematic KKN program include coordinating with the Village Head, providing guidance to students at least twice a month, guiding students in preparing work programs, activity matrices, daily notes, mentoring teaching literacy, and writing reports, as a mediator between students with the village and as a representative of LPPM IKIP Mataram in the community, as well as with the Village Head to monitor and evaluate the implementation of KKN. Based on the questionnaire data analysis related to DPL performance in carrying out KKN guidance, it can be concluded that DPL in carrying out KKN guidance is a good category. This can be indicated by the achievement of DPL performance in carrying out its main tasks. To facilitate understanding of the achievement of DPL performance in carrying out KKN guidance, the following chart is displayed (Figure 4).

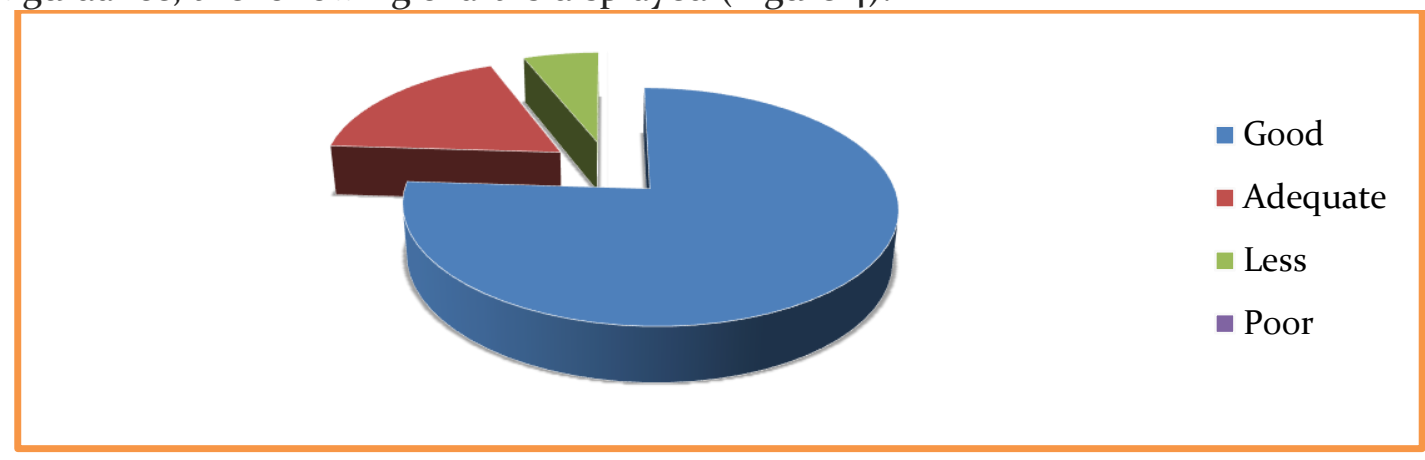

Figure 4. Performance of KKN DPL

Based on Figure 4, it can be explained that as many as $76.47 \%$ responded that DPL performance in carrying out KKN guidance was good, as much as $17.65 \%$ was quite good, and as much as $5.88 \%$ was not good. Based on the findings in the field, DPL which is classified as not good in 
JPPM (Jurnal Pendidikan dan Pemberdayaan Masyarakat), 7 (1), 2020 - 31

Muhammad Arief Rizka, Akhmad Sukri, Dira Permana

carrying out PPL guidance is indicated from the low level of DPL attendance in carrying out KKN guidance to students, besides the lack of coordination and communication between DPL and the village head.

The main tasks of the Village Head in implementing the Thematic KKN program include; (1) coordinating the implementation of Thematic KKN in the village; (2) together with DPL guiding the implementation of Thematic KKN; (3) as a mediator between DPL, students, and the community; and (4) assessing the implementation of students' Thematic KKN in the village. Based on the questionnaire data analysis related to the performance of the Village Head in carrying out Thematic KKN guidance, it can be concluded that the Village Head in carrying out the KKN guidance is a good category. This can be indicated by the achievement of the Village Head's performance in carrying out his main tasks. To facilitate the understanding of the achievement of the Village Head's performance in carrying out guidance for Thematic KKN students in the village, the following chart is displayed (Figure 5).

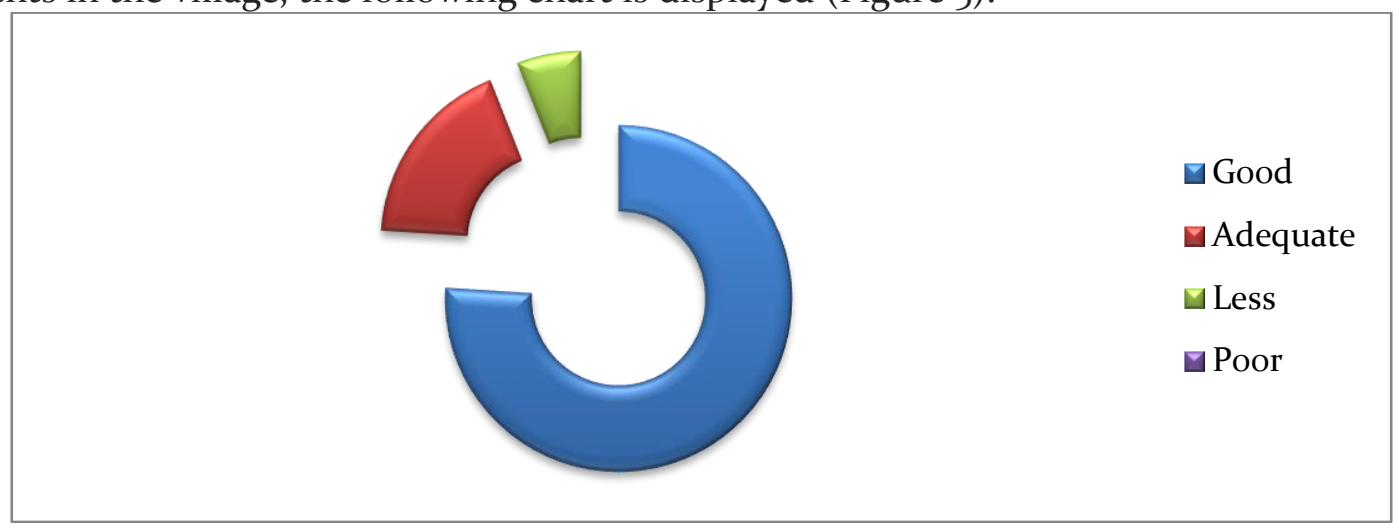

Figure 5. Village Head Performance

Based on Figure 5, it can be explained that as much as $82.35 \%$ responded that the performance of the Village Head in carrying out guidance and assistance for Thematic KKN participants was good, $11.76 \%$ was quite good, and $5.88 \%$ was not good enough. Based on the findings in the field, the Village Head who was classified as not good in carrying out guidance and assistance for Thematic KKN participants indicated that there were still Village Heads who lacked professional guidance and carried out a subjective assessment process.

Problems of Thematic Community Service Program-based Basic Literacy Education

Based on information and findings in the field, there are several problems arise in the implementation of the Thematic Community Service Program in the village. The problems that arise are inseparable from the lack of coordination between the parties directly involved in the field (Thematic KKN location). The problems that arise in the implementation of the Thematic KKN include; (1) some Thematic KKN students have poor social communication skills, which causes the process of interaction with community members to not run well; (2) there are still students who have low literacy teaching skills because of the mastery of the local village language; (3) there are several numbers of DPLs that do not carry out the task of Thematic KKN guidance professionally. This can be seen from the minimal level of DPL attendance to villages (KKN locations), causing a lack of communication and coordination with students and village parties; (4) the presence an 'individual' of the Village Head who does not conduct professional KKN guidance, this is known from several 'personal' cases that arise and have implications for subjective assessment of KKN students; and (5) The earthquake disaster that struck the island of Lombok in August 2018 which implied on the delay of the Thematic KKN program continuity, especially in terms of teaching basic literacy for illiterate citizens.

Related to problems that arise in the implementation of the Thematic Community Service Program in the village community, LPPM IKIP Mataram seeks to overcome these problems by using an integrated approach through improved coordination and communication with various 


\section{JPPM (Jurnal Pendidikan dan Pemberdayaan Masyarakat), 7 (1), 2020 - 32}

Muhammad Arief Rizka, Akhmad Sukri, Dira Permana

parties (DPL, Village Heads, students, and residents of surrounding communities). The mechanism used to overcome these problems was that; (1) if the students (participants) of Thematic KKN face a certain problem, the Village Head as the KKN Coordinator in the village seeks to overcome it by coordinating and providing reports to the DPL to be followed up. Furthermore, if it has not been able to solve the problem, DPL coordinates with LPPM IKIP Mataram (through the mediation of the regional coordinator) to find the best solution to overcome the problem. (2) if DPL has a problem, students (KKN participants) coordinate with the Village Head as KKN Coordinator in the village trying to do intensive communication to be able to overcome it, then if coordination and communication between students and the Village Head have not been able to resolve the DPL problem, students and the village head through the regional coordinator, coordinated with LPPM IKIP Mataram to find the best solution to overcome the problem. (3) If the Village Head has a problem, students (KKN participants) coordinate with DPL to try to make intensive communication to be able to overcome the problem. Then, in case that coordination and communication between students and DPL have not been able to solve the problem, DPL coordinates and reports to LPPM IKIP Mataram (through a regional coordinator) aiming at looking for the best solution to overcome the problem. So far, the problems that have arisen in the implementation of the Thematic KKN program have been resolved well. This is inseparable from the intensity of communication and synergistic cooperation between all parties directly involved in the implementation of the Thematic KKN. Besides, efforts to overcome these emerging problems use a familial approach in addition to implementing a win-win solution strategy.

\section{Monitoring and Evaluation}

Monitoring is an activity to find out whether the program made runs well as it should be as planned, are there any obstacles that occur and how the program implementers overcome these obstacles. Monitoring of an ongoing planning result is a good control tool in the entire implementation process (Suryana, 2010). Monitoring is an activity carried out by LPPM IKIP Mataram by involving bureaucratic officials on a periodic (scheduled) basis to carry out the process of supervision, monitoring as well as supervision of the implementation of the Thematic Community Service Program.

In the process of monitoring, the Monitoring and Evaluation Team that has been formed by LPPM IKIP Mataram seeks to go directly to the KKN location to get factual information and identify problems that occur during the Thematic KKN implementation process which serves as one of the references for future improvement and refinement of the program. Monitoring activities were carried out during the Thematic KKN process, which was in the 3-4 week program implementation. The implementation of Thematic KKN monitoring is divided into two patterns, that is; (1) the monitoring and evaluation team monitors the literacy learning location at the Thematic KKN location; and (2) the monitoring and evaluation team monitors the village office and student posts. This pattern is carried out to obtain holistic information related to the existence and development of the ongoing Thematic KKN program. So far, based on information from the monitoring and evaluation team, the findings of the existing problems in the field are related to the unstable conditions of motivation to learn from illiterate people due to earthquake disasters whose intensity of occurrence is very frequent which psychologically impacts on the society learning interest.

Evaluation is a stage that is closely related to monitoring activities since evaluation activities can use data provided through monitoring activities. In planning activity of evaluation should be an inseparable part, so it can be said as a complete activity. Evaluation is an activity to collect data, present accurate and objective information (Aditya et al., 2018) (Stufflebeam, 2003). Evaluation is directed to control and control the achievement of objectives. Evaluation deals with the results of information about values and provides an overview of the benefits of a policy. The term evaluation is close to interpretation, giving a number and rating. The Evaluation 


\section{JPPM (Jurnal Pendidikan dan Pemberdayaan Masyarakat), 7 (1), 2020 - 33}

Muhammad Arief Rizka, Akhmad Sukri, Dira Permana

aims to find out whether the program achieved the expected goals or not, the evaluation emphasizes more on the aspects of the results achieved (Suryana, 2010).

Evaluation is intended to find out the results of basic literacy learning conducted by Thematic KKN students. In the evaluation of the Thematic KKN in the academic year 2018/2019, the Basic Literacy Education Test Examination was held regarding the guidelines for conducting the final assessment of basic literacy education (Direktorat Pembinaan Pendidikan Keaksaraan dan Kesetaraan, 2015). The basic literacy education test is carried out in each KKN village location where the number of learning people who take the basic literacy test is 802 people. The results of the implementation of the basic literacy test are as follows (Figure 6).

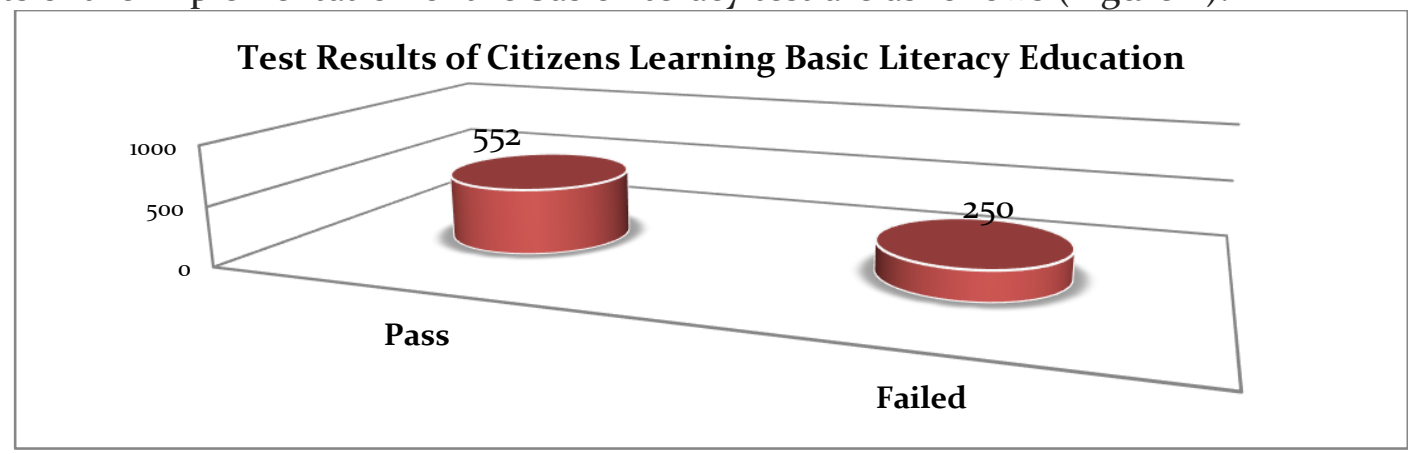

Figure 6. Test Results of Citizens Learning Basic Literacy Education

Based on Figure 6 regarding the Minimum Completion Criteria (KKM) Final Assessment of Basic Literacy Examination with a score of 55 (Fair criteria), it can be explained that from the total number of 802 learning citizens who took the basic literacy test, as many as 552 people were declared graduated and as many as 250 learning citizens declared as not passing or not fulfilling the Basic Literacy Assessment KKM. There are still many learning residents who do not meet the KKM basic literacy education as they are strongly influenced by natural disasters that have occurred and shaken the residents' psychological aspects on the stability of literacy learning in the field. However, the number of graduations achieved was also one of the successful implementation of the IKIP Mataram Thematic KKN in the academic year 2018/2019.

Follow up of Thematic Community Service Program-based Basic Literacy Education

To achieve the objectives of a comprehensive Thematic KKN program, aspects of program follow-up are very fundamental. The follow-up aims to provide competency strengthening for the acquisition of student experience during the KKN process. The pattern of follow-up to the Thematic KKN program is carried out by holding EXPO KKN activities by presenting the best photo and video documentary works from students and Thematic KKN groups. The work displayed at the EXPO Community Service Program is a photo and video documentary on basic literacy learning that has been carried out during existed in the middle of the community. Besides, the follow up is to give rewards to students and the best KKN groups and DPLs. This rewarding process is carried out with a crosscheck-selective approach; (1) for the best KKN students and groups, the awarding is based on the assessment of reports and documentary videos of KKN groups integrated with the field monitoring and evaluation team report data; (2) while for the best DPLs, rewards are based on the performance of DPLs during KKN implementation and integrated with the field monitoring and evaluation team data.

Based on the crosscheck-selective process, 10 students with the best KKN photos were obtained, the KKN groups with the best videos were 5 groups, and the best DPL were 10 lectures. It is expected that through the pattern of program follow-up by giving this reward, it can provide appreciation as well as dedication to succeed in the upcoming Thematic KKN program. Besides, this reward is also expected to be an 'instrument' to further improve the students and lectures performance and professionalism during the community service program. 


\section{JPPM (Jurnal Pendidikan dan Pemberdayaan Masyarakat), 7 (1), 2020 - 34}

Muhammad Arief Rizka, Akhmad Sukri, Dira Permana

\section{CONCLUSIONS}

Conclusions obtained from the results of this study include; (1) the implementation of the Basic Literacy Education based Thematic KKN Program at IKIP Mataram has been carried out through the stages of registration, debriefing, implementation, monitoring, and evaluation; (2) the results of the evaluation of the implementation of the Basic Literacy Education based Thematic KKN Program at IKIP Mataram have succeeded in teaching 802 illiterate people in Central Lombok Regency with data on the results of the basic literacy test that have been carried out that as many as 552 people were declared to have passed and as many as 250 people declared not passed or having yet met the KKM Basic Literacy Assessment; and (3) The main obstacle of the implementation of the Thematic KKN is the earthquake disaster that struck the island of Lombok so that it has implications on the not optimal implementation of basic literacy learning for residents in the field. However, KKN students with DPL assistance, the Village Head, and the LPPM Team have made an optimal effort to the continuity of the Thematic KKN implementation in the community.

The constructive suggestions made in response to the results of this study include; (1) follow-up to the thematic KKN program is needed to reach other illiterate citizens by expanding the range of KKN locations to other regency areas; (2) Optimizing cooperation with other tertiary institutions, government and private institutions to support operational resources in the field, (3) development of a Management Information System (SIM) for Thematic KKN program management, and (4) Optimizing the Thematic KKN Concept with the Empowering approach and Learning to Live Together.

\section{REFERENCES}

Aditya, R., Tamba, W., \& Rizka, M. A. (2018). Evaluasi implementasi program kelompok usaha bersama (KUBE) dalam mengatasi kemiskinan di Kota Mataram. Jurnal Kependidikan: Jurnal Hasil Penelitian Dan Kajian Kepustakaan Di Bidang Pendidikan, Pengajaran Dan Pembelajaran, 4(2). https://doi.org/10.33394/jk.v4i2.1129

Basukiyatno, B., Ponoharjo, P., Susongko, P., \& Suyono, D. (2004). Evaluasi kuliah kerja nyata Universitas Pancasakti Tegal tahun 2003. CERMIN, 36(036). http://ejournal.upstegal.ac.id/index.php/Cermin/article/view/333

Direktorat Pembinaan Pendidikan Keaksaraan dan Kesetaraan. (2015). Panduan penyelenggaran penilaian akhir pendidikan keaksaraan dasar. Kementerian Pendidikan dan Kebudayaan, Direktorat Jenderal PAUD \& Pendidikan Masyarakat.

Indrianti, D. T., Khutobah, K., \& Latif, M. A. (2017). Potensi kearifan lokal dalam pendidikan keaksaraan fungsional pada masyarakat perdesaan di Kabupaten Jember. Journal of Nonformal Education, 3(2), 140-148. https://doi.org/10.15294/jne.v3i2.10949

Kuntoro, S. A. (2007). Pendidikan keaksaraan untuk mencerdaskan kehidupan masyarakat. JIV, 2(1), 23-27. https://doi.org/10.21009/JIV.0201.3

LPPM IKIP Mataram. (2014). Buku pedoman program PPL-KKN Terpadu IKIP Mataram. IKIP Mataram.

Masniladevi, Ritawati, \& Helsa, Y. (2018). Calistung literacy through the application of Lectora. Journal of Physics: Conference Series, 1088, 012079. https://doi.org/10.1088/17426596/1088/1/012079

Nurazizah, N. (2018). Pengembangan perangkat pembelajaran pendidikan keaksaraan dasar berbasis kearifan lokal pada komunitas adat terpencil (KAT) Suku Dayak Meratus. JIVJurnal Ilmiah Visi, 13(2), 123-134. https://doi.org/10.21009/JIV.1302.6

Oktapiani, M., Akbar, M., \& Karnati, N. (2019). Evaluation of the implementation of basic literacy education program in Bogor Regency, Indonesia. Journal of Physics: Conference Series, 1232, 012032. https://doi.org/10.1088/1742-6596/1232/1/012032 
JPPM (Jurnal Pendidikan dan Pemberdayaan Masyarakat), 7 (1), 2020 - 35

Muhammad Arief Rizka, Akhmad Sukri, Dira Permana

Rasyid, S. Z. (2017). NTB peringkat kedua angka buta huruf di Indonesia. HarianNusa.Com. https://hariannusa.com/2017/og/o9/ntb-peringkat-kedua-angka-buta-huruf-indonesia/

Retnowati, E. (2015). Analisis fungsionalisasi hasil belajar warga belajar keaksaraan di Kecamatan Sukamakmur Kabupaten Bogor. Jurnal Ilmiah Visi, 10(1), 55-66. https://doi.org/10.21009/JIV.1001.7

Rizka, M. A. (2014). Evaluasi implementasi program kursus wirausaha desa (KWD) untuk mengatasi pengangguran. Jurnal Kependidikan, 13(4), 369-381.

Rizka, M. A. (2016). Evaluasi implementasi program PPL-KKN Terpadu IKIP Mataram tahun akademik 2015/2016. Laporan Penelitian Internal.

Shantini, Y. (2010). Model pendidikan keaksaraan fungsional orientasi budaya lokal untuk peningkatan mutu layanan belajar. Jurnal Pendidikan Luar Sekolah, 5(2). https://ejournal.upi.edu/index.php/pls/article/view/1203

Suryana, A. (2010). Strategi monitoring dan evaluasi (Monev) system penjaminan mutu internal sekolah. Jurnal.

Wulandari, A. (2018). Evaluation of basic literacy educator as social change agent. Jurnal Pendidikan Ilmu Sosial, 27(1), 11-21. https://doi.org/10.17509/jpis.v27i1.11659 